\title{
Strategi Pengembangan Program Pemberdayaan Usaha Mikro dan Kecil Melalui Pembiayaan Usaha Syariah pada Badan Amil Zakat Nasional (BAZNAS) Kota Banda Aceh
}

\author{
SARBOINI \\ Fakultas Ekonomi, Universitas Serambi Mekkah, \\ Jalan Batoh, Lueng Bata, Kota Banda Aceh, Provinsi Aceh, Indonesia \\ sarboinise@serambimekkah.ac.id \\ Misna MAISARAH * \\ Fakultas Ekonomi, Universitas Serambi Mekkah, \\ Jalan Batoh, Lueng Bata, Kota Banda Aceh, Provinsi Aceh, Indonesia \\ misnamaisarah@gmail.com \\ MARYAM \\ Fakultas Ekonomi, Universitas Serambi Mekkah, \\ Jalan Batoh, Lueng Bata, Kota Banda Aceh, Provinsi Aceh, Indonesia \\ maryam@serambimekkah.ac.id \\ IMILDA \\ Fakultas IImu Komputer, AMIK Indonesia, \\ Jalan T. Nyak Arief No. 400, Kota Banda Aceh, Provinsi Aceh, Indonesia \\ imilda@amikindonesia.ac.id
}

\section{Article's history:}

Received 6 June 2021; Received in revised form 11 December 2021; Accepted 15 December, 2021; Published 30 December 2021. All rights reserved to the Lembaga Otonom Lembaga Informasi dan Riset Indonesia (KITA INFO dan RISET).

Suggested citation:

Sarboini, S., Mausarah, M., Maryam, M., Imilda, I. 2021. Strategi Pengembangan Program Pemberdayaan Usaha Mikro dan Kecil Melalui Pembiayaan Usaha Syariah pada Badan Amil Zakat Nasional (BAZNAS) Kota Banda Aceh. JEMSI (Jurnal Ekonomi, Manajemen, dan Akuntansi), Volume 7 (2): 42-59. DOI: https://doi.org/10.35870/jemsi.v7i2.605.

\section{ABSTRAK:}

Tujuan penelitian ini untuk mengetahui strategi pengembangan program pemberdayaan usaha mikro dan kecil melalui pembiayaan usaha syariah pada badan amil zakat nasional (baznas) Kota Banda Aceh. Populasi penelitian ini adalah usaha mikro dan kecil yang diberdayakan oleh Badan Amil Zakat Nasional Kota Banda Aceh, dan model penarikan sampel menggunakan teknik purposive sampling. Hasil penelitian menunjukkan bahwa program pembiayaan usaha syariah (Pusyar) merupakan kerjasama Badan Amil Zakat Nasional Kota Banda Aceh Pemerintah Kota Banda Aceh, konsep dari program ini adalah memberikan pembiayaan pada usaha mikro dan kecil dengan tidak membebankan biaya tambahan apapun kepada peminjam, karena biaya margin, administrasi dan asuransi ditanggung oleh Badan Amil Zakat Nasional Kota Banda Aceh yang diambil dari dana infaq dan sedekah. Semua stakeholder yang terlibat memiliki peran dan tanggung jawab masing-masing agar program pembiayaan ini berjalan dengan lancar dalam penyediaan dana sebagai pinjaman yang diberikan kepada UKM di Kota Banda Aceh. Sehingga dapat disimpulkan bahwa pembiayaan usaha syariah strategi yang digunakan merupakan bentuk kerja sama Badan Amil zakat Nasional Kota Banda Aceh Pemerintah Kota Banda Aceh dengan konsep dari program ini adalah memberikan pembiayaan pada Usaha Mikro dan Kecil.

Kata Kunci: Program Pembiayaan; Usaha Mikro dan Kecil; BAZNAS.

JEL Classification: G23; 012. 


\section{PENDAHULUAN}

Zakat memiliki arti sejumlah harta tertentu yang diwajibkan oleh Allah SWT diserahkan kepada orangorang yang berhak. Menurut UU No. 38 Tahun 1998 tentang pengelolaan zakat, pengertian zakat adalah harta yang wajib disisihkan oleh seorang muslim atau lembaga yang dimiliki oleh orang-orang muslim yang sesuai dengan ketentuan agama untuk diberikan kepada yang berhak menerimannya (Mardani, 2015). Dalam pengelolaan zakat, Al-Qur'an menyebutkan kata 'amilin dalam salah satu dari delapan ashnaf yang berhak menerima dana zakat (QS. Al-Taubah). Al-Qurtubi menafsirkan kata 'amilin sebagai orang-orang yang ditugaskan (oleh imam/pemerintah) untuk mengambil, menuliskan, menghitung dana zakat yang diambil dari muzakki untuk kemudian diberikan kepada golongan yang berhak menerimanya (Septiandani, 2012). Di Indoensia lembaga yang bertugas mengelola zakat diantaranya adalah Badan Amil Zakat Nasional (BAZNAS) maupun lembaga amil zakat, agar dana yang terkumpul dapat tersalurkan secara optimal (Aziz, 2016). BAZNAS memiliki tugas melakukan pengumpulan, pendistribusian, dan pendayagunaan zakat, kepada masyarakat agar dapat membentuk Lembaga Amil Zakat (LAZ). Dengan adanya sinergisitas dua lembaga tersebut akan meningkatkan pelayanan kepada muzakki yang semakin banyak, dan penanganan terhadap mustahiq, permasalahan kemiskinan bisa semakin berkurang, dan kaum dhuafa bisa mampu dalam mencukupi kehidupannya (Septiandani, 2012). Namun fenomena yang terjadi dilapangan, Usaha Mikro Kecil (UMK) memiliki peran penting untuk perekonomian Indonesia. Sektor usaha mikro kecil ini mampu menyediakan lapangan kerja dan mampu meningkatkan peran masyarakat miskin dalam struktur ekonomi. Usaha mikro kecil ini juga mampu menopang perekonomian nasional, untuk itu pentingnya peran lembaga keuangan syariah dalam peminjaman modal dan sistem pemberdayaan guna mendukung perkembangan usaha mikro kecil. Dengan prinsip ekonomi syariah, lembaga keuangan tersebut dapat mendukung usaha mikro kecil melalui program kemitraan guna memperluas pembiayaan syariah, model pinjaman cash collateral dari instansi, serta peningkatan pembiayaan berdasarkan prinsip bagi hasil. Sistem ini dapat memberikan kemudahan bagi pelaku usaha mikro kecil untuk mendapat modal (Wahyudi, 2016).

Tidak dapat dipungkiri bahwasanya usaha mikro kecil memberikan kontribusi cukup besar dalam meningkatkan pendapatan masyarakat khususnya masyarakat berpenghasilan rendah (MBR). Melihat keberadaan usaha mikro kecil di Kota Banda Aceh yang semakin meningkat, usaha mikro kecil memiliki peran strategis, namun sektor ini juga dihadapkan berbagai permasalahan yang pada umumnya bersumber dari kelemahan yang terjadi dalam diri usaha mikro kecil. Permasalahan yang sering dihadapi pengusaha mikro kecil meliputi kurangan modal dalam bekerja maupun investasi, kesulitan dalam melakukan pemasaran produk hasil usaha, akibat keterbatasan informasi mengenai perubahan dan peluang pasar, kesulitan dalam pengadaan bahan baku khususnya bahan baku yang masih harus diimpor selain itu waktu yang cukup lama dan harga yang mahal, keterampilan sumber daya manusia (pekerja dan manajer) masih rendah, teknologi yang digunakan masih rendah yang ditandai oleh peralatan produksi yang digunakan masih tradisional, kesulitan dalam administrasi pembukuan (Wahyudi, 2016).

Mengingat keberadaan usaha mikro kecil bagi masyarakat sangat penting dipertahankan untuk mengatasi berbagai masalah-masalah ekonomi dan sosial, sebagai upaya mengatasi pengangguran serta pengentasan kemiskinan, maka usaha mikro kecil sangat perlu untuk diberdayakan oleh pemerintah, tidak hanya pemerintah pusat tetapi juga pada pemerintah daerah diharapkan dapat memberdayakan usaha mikro kecil secara optimal karena setiap manusia atau setiap masyarakat memiliki potensi yang dapat dikembangkan. Salah satu lembaga yang menjadi mitra dalam upaya menyelesaikan permasalahan yang dihadapi oleh pelaku usaha mikro kecil khususnya di Kota Banda Aceh melalui BAZNAS Kota Banda Aceh.

BAZNAS Kota Banda Aceh merupakan suatu bagian yang terintegrasi dari Badan Amil Zakat Nasional yang dikelola pemerintah Kota Banda Aceh yang bergerak di program penyaluran zakat bagi maasyarakat Kota Banda Aceh, termasuk bagi usaha-usaha yang bersifat produktif. BAZNAS Kota Banda Aceh merupakan lembaga yang bergerak di bidang permodalan dan pemberdayaan berbasis syariah. Target utamanya adalah masyarakat miskin yang seraca ekonomi tidak dapat tersentuh oleh lembaga formal seperti sektor perbankan namun sektor kecil lainnya yang memiliki peluang usaha. Berbagai program dan kegiatan telah dilakukan oleh Baznas Kota Banda Aceh dalam upaya meningkatkan kemampuan pelaku usaha mikro kecil, salah satunya melalui program usaha syari'ah dan Hibah Modal Langsung (yaitu pemberian bantuan modal usaha kepada masyarakat miskin yang mempunyai usaha kecil maupun yang akan membuka usaha kecil). 


\section{TINJAUAN KEPUSTAKAAN}

\section{Konsep Pemberdayaan}

Pemberdayaan adalah proses pengambilan keputusan orang-orang yang secara konsekuen melaksanakan keputusan-keputusan yang telah diambil tersebut. Orang-orang yang telah mencapai tujuan kolektif diberdayakan melalui kemandiriannya, bahkan merupakan sebuah keharusan untuk lebih diberdayakan melalui usaha mereka sendiri dan akumulasi pengetahuan, keterampilan dan sumber daya lainnya. Istilah lain keberdayaan dalam konteks pengembangan masyarakat adalah kemampuan individu yang bersenyawa dengan invidu-individu lainnya dalam masyarakat untuk membangun keberdayaan diri mereka yang bersangkutan (Hikmat, 2010).

Memberdayakan masyarakat adalah langkah atau proses mengupayakan unsur-unsur keberdayaan dalam masyarakat sehingga mereka mampu meningkatkan harkat dan martabat dan keluiar dari sebuah ketergantungan yang mengkondisikan mereka dalam perangkap kemiskinan dan keterbelakangan, atau dengan istilah lain memandirikan masyarakat (Anwar, 2014). Proses pemberdayaan yang menekankan pada proses memberikan kemampuan kepada masyarakat menjadi berdaya, mendorong atau memotivasi individu agar mempunyai kemampuan atau keberdayaan untuk menentukan pilihan hidupnya. Lebih lanjut dikatakan bahwa pemberdayaan harus ditujukan pada kelompok atau lapisan masyarakat yang tertinggal (Mardikanto, 2015).

\section{Konsep Zakat}

Zakat berasal dari kata zaka yang berarti baik, berkah, tumbuh, bersih dan bertambah. Sedangkan menurut istilah fikih, zakat adalah nama bagi sejumlah harta tertentu yang dikeluarkan, dan diwajibkan oleh Allah SWT untuk diserahkan kepada orang yang berhak menerimanya (mustahiq) dari orang-orang yang wajib mengeluarkan (muzakki) (Khasanah, 2010). Secara etimologis, zakat berarti sejumlah harta tertentu yang diwajibkan oleh Allah SWT diserahkan kepada orang-orang yang berhak. Menurut UU No. 38 Tahun 1998 tentang pengelolaan zakat, pengertian zakat adalah harta yang wajib disisihkan oleh seorang muslim atau lembaga yang dimiliki oleh orang-orang muslim yang sesuai dengan ketentuan agama untuk diberikan kepada yang berhak menerimannya (Mardani, 2014). Zakat adalah salah satu poin dalam rukun Islam. Oleh sebab itu, setiap muslim yang telah memenuhi kriteria tertentu wajib membayar zakat. Seorang muslim yang menunaikan zakat disebut sebagai muzaki yang berarti orang yang menyucikan jiwa dan hartanya. Muzaki disunnahkan menyalurkan zakatnya kepada organisasi pengelola zakat (amil) untuk kemudian disalurkan kepada orang yang berhak menerima zakat (mustahik). Mustahik zakat dibatasi kepada delapan golongan, dan golongan yang paling diprioritaskan adalah fakir dan miskin (Ali dkk, 2016). Menurut Chapra (2000) dalam Kuncoro (2016) menyatakan bahwa zakat mempunyai makna literal, yaitu: penyucian (thaharah), pertumbuhan (nama'), keberkatan (barakah), dan pujian (madh). Pada hakikatnya zakat adalah kewajiban seorang muslim untuk membayar sebagian harta kekayaan atau hasil pertanian, jika kekayaan tersebut melebihi batas nishab suatu kadar tertentu sebagai bagian dari kewajiban keagamaan yang harus ditunaikan.

Dasar Hukum Zakat

Perintah menunaikan zakat beriringan dengan perintah shalat karena keduanya memiliki tujuan yang hampir sama, yaitu perbaikan kualitas kehidupan masyarakat. Tujuan dari zakat adalah untuk membersihkan diri dari sifat rakus dan kikir, dan mendorong manusia untuk bersikap dermawan serta simpati terhadap orang lain. Sehingga kehidupan manusia akan terhindar dari sifat fakhsya (kejahatan) dan mungkar (kerusakan) (Khasanah, 2010). Dalam Al-Qur'an zakat disebutkan 30 kali berdampingan dengan kalimat shalat sebanyak 27 kali (Pusat Kajian Strategi/Puskas Baznas, 2017). Kedudukan antara shalat dan zakat adalah sejajar. Zakat adalah rukun Islam terpenting setelah dua kalimat sahadat dan shalat. Hukum menunaikannya adalah wajib berdasarkan firman Allah SWT:

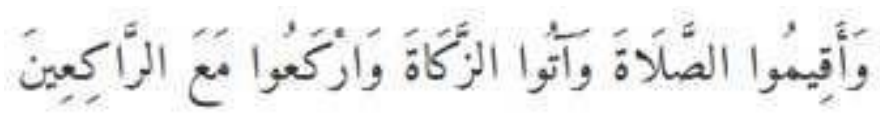

"Dan dirikanlah shalat, tunaikanlah zakat dan rukuklah bersama orang-orang yang ruku'." (QS. Al-Baqarah:43). 


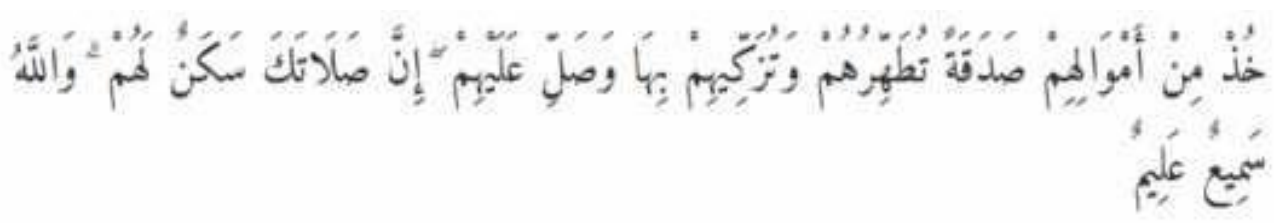

"Ambillah zakat dari sebagian harta mereka, dengan zakat itu kamu membersihkan dan berdoalah untuk mereka. Sesungguhnya doa kamu itu (menjadi) ketenteraman jiwa bagi mereka. dan Allah Maha mendengar lagi Maha Mengetahui Ambillah zakat dari sebagian harta mereka, dengan zakat itu kamu membersihkan dan mensucikan mereka dan berdoalah untuk mereka. Sesungguhnya doa kamu itu (menjadi) ketenteraman jiwa bagi mereka. dan Allah Maha mendengar lagi Maha Mengetahui" (QS. At-Taubah:103).

Dalam Madhzab Hambali menegaskan zakat adalah hak yang "wajib" dikeluarkan dari harta yang khusus dan waktu yang khusus pula (Bank Indonesia, 2016). Dalam Madzhab Hambali diatas yang dimaksudkan "kelompok khusus" adalah fakir, miskin, amil, muallaf, gharim, ibnu sabil, fissabilillah, riqab. Dalam hal ini, yang dimaksud dengan "waktu yang khusus" adalah ketika sempurna kepemilikian (haul) dalam waktu setahun baik berupa binatang ternak, uang, biji-bijian, buah-buahan, madu, dan barang tambang yang digali yang semuanya wajib untuk dizakati. Disisi lain, yang dimaksud dari "lain waktu" adalah ketika hari raya dan pada saat itu disebut dengan zakat fitrah.

Qardhawi (1999) dalam Widiastuti dan Rosyidi, (2015) menjelaskan betapa penting dan wajibnya zakat yang harus ditunaikan sebagai umat islam. Dalam sebuah hadits lbnu Abbas menyebutkan bahwa ketika Nabi Muhammad saw mengirimkan Mu'adz bin jabal ke Yaman, beliau berkata: "Beritahukan kepada mereka bahwa Allah mewajibkan pemungutan zakat dari orang-orang berada di kalangan mereka untuk diberikan kepada orang-orang miskin dari kalangan mereka juga. Bila sedekah itu telah dipungut, hati-hatilah kamu terhadap kemuliaan harta itu dan hati-hati pula terhadap doa mereka yang tertindas karena tidak ada batas antara mereka dan Allah" (HR Jamaah dari Ibnu Abbas).

Dari beberapa penjelasan dalil diatas jelas bahwa hukum menunaikan zakat adalah wajib bagi seorang muslim. Dan bagi mereka yang tidak mau menunaikan zakat maka mereka melanggar ketetapan yang telah Allah SWT dan bagi orang-orang yang melanggar ketetapan Allah maka mereka adalah orang- orang kafir (Qardhawi, 1999) dalam Widiastuti dan Rosyidi, 2015). Rasulullah memberikan gambaran tentang orang yang tidak mau membayar zakat ketika mengalami siksa neraka kelak. Abu hurairah berkata bahwa Rasulullah Saw bersabda, "Barang siapa yang diberikan harta lalu tidak mau mengeluarkan zakatnya, ia akan dibuat seumpama ular botak yang mempunyai dua buah kismis yang dikalungkan kepadanya pada hari kiamat, lalu menggigit dengan dua rahanngnya. Kemudian berkata: "Akulah hartamu" (HR. Bukhari). Sedangkan untuk hukuman di dunia, maka suatu Negara berhak menggunakan seluruh media untuk memperoleh zakat wajib, diantara sanksi- sanksi pidana ini adalah denda (Muhammad, 2007 dalam Kuncoro, 2016).

Mardani (2015) juga mengemukakan melaksanakan zakat merupakan dasar untuk menegakkan struktur sosial Islam. Zakat bukan dalam bentuk sedekah biasa, namun berupa iuran wajib yang diberikan kepada orang yang berhak. Dalam Al-Qura'an dan Hadits menyebutkan tentang perintah melaksanakan zakat, sebagaimana firman Allah SWT dalam QS. Al-Baqarah: 110, QS. Al-Hajj: 78, QS. Al-Muzammil: 20, dan lain sebagainya. Kata zakat telah disebutkan dalam Al-Quran sebanyak tiga puluh kali, diantaranya disebutkan dalam konteks yang sama dengan shalat meski tidak dalam satu ayat. Dan sebagian ahli menjelaskan bahwa kata zakat dihubungkan dengan shalat, sehingga hukum dari zakat itu sendiri adalah wajib. Di dalam Al-Qur'an juga menggunakan kata shadaqah untuk mengungkapkan maksud dari zakat, sebagaimana dalam QS. Al-Taubah ayat 58, 60 dan 103 serta infaq dalam QS. Al-Taubah ayat 34. Dalam QS. Al-Taubah ayat 34 menyebutkan zakat adalah infaq karena pada hakikatnya zakat merupakan penyerahan harta untuk kebajikan-kebajikan yang diperintahkan Allah SWT. Dan disebut sedekah (shadaqah) karena salah satu tujuan utama untuk mendekatkan diri (taqarrub) kepada Allah SWT. Zakat juga disebut haq karena zakat merupakan ketetapan yang bersifat pasti dari Allah SWT yang harus diberikan kepada yang berhak menerimanya (mustahiq) (Mardani, 2015).

Selain itu, diperkuat pula dengan perintah Nabi Muhammad SAW kepada Mu'adz bin Jabal yang diperintahkan untuk mengambil dan mengumpulkan harta (zakat) dari orang-orang kaya yang kemudian dikembalikan kepada fakir miskin dari kelompok mereka. Sehingga dapat disimpulkan bahwa zakat itu wajib dikeluarkan, tidak hanya karena perintah agama tetapi memberikan sebagian harta yang Allah SWT titipkan melalui kita kepada orang-orang yang membutuhkan (Mardani, 2015). Kata shadaqah dan shadaqat, di dalam AlQur'an disebutkan 12 kali yang semuanya turun di Madinah (Madaniyah). Shadaqah memiliki pengertian yang 
luas, di mana pengertian tersebut terbagi menjadi dua macam yaitu materil atau fisik dan nonfisik. Berdasarkan sifatnya yang materil atau fisik, terbagi menjadi dua macam, yaitu (Mardani, 2015) :

1. Fardlu (wajib). Fardlu atau wajib terdiri dari :

a. Fadlu'ain (perorangan), zakat terdiri dari zakat fitrah (zakat yang diperuntukkan atas diri atau jiwa) dan zakat maal (zakat yang berlaku atas harta manusia).

b. Fardlu kifayah yaitu infak.

2. Shadaqah adalah sunnah.

Menurut kompilasi hukum ekonomi syariah, shadaqah merupakan barang yang diberikan semata-mata untuk mendapatkan pahala.

\section{Fungsi Zakat dalam Tinjauan Ekonomi}

1. Zakat mengandung arti suci, bersih, berkembang dan bertambah, selain itu memiliki makna yang penting bagi manusia baik secara individu ataupun masyarakat. Zakat diberikan dengan tujuan membantu penduduk miskin, sehingga terjalin hubungan antara orang yang miskin dan yang kaya. Jika ditinjau dari sistem ekonomi Islam, zakat sebagai salah satu alat untuk mencapai tujuan. Para pakar ekonomi Islam berpendapat bahwa zakat sebagai alat pengamanan sosial yang dapat menetralisasi keresahan sosial dan mengentaskan kemiskinan (Khasanah, 2010).

2. Sementara menurut Yusuf Qardhawi dalam penelitian Umrotul, sebagai salah satu pakar ekonomi Islam berpendapat bahwa zakat harta dapat menjadi sumber potensial untuk menghapuskan kemiskinan. Sampai saat ini, pengelolaan zakat menjadi sangat krusial karena masyarakat memandang zakat sebagai saluran untuk membantu pemenuhan kebutuhan kaum fakir miskin. Jika dilihat dari sudut pandang ekonomi Islam, zakat merupakan sebuah instrumen yang berfungsi memutar roda ekonomi secara terus menerus dan tidak boleh berhenti. Sehingga zakat menjadi salah satu solusi mengatasi masalah ekonomi sosial dalam jangka pendek. Berikut ini tujuan dari diwajibkannya zakat, yaitu (Mardani, 2015):

\section{Lembaga Pengelola Zakat}

Organisasi pengelola zakat ialah institusi yang bergerak di bidang pengelolaan dana zakat, infaq, dan shadaqah. Dalam sejarah Islam lembaga pengelola zakat dikenal dengan nama Baitul Maal. Lembaga ini sudah ada sejak zaman Khalifah Umar Bin Khaththab, sebagai institusi yang memobilisasi dana dan daya dari umat yang digunakan sebagai upaya meningkatkatkan harkat, derajat dan martabat (Asnaini, 2013).

1. Badan Amil Zakat Nasional

Dalam Undang-Undang Republik Indonesia Nomor 23 Tahun 2011 Tentang Pengelolaan Zakat menjelaskan bahwa untuk melaksanakan pengelola zakat, pemerintah membentuk BAZNAS. Dimana BAZNAS adalah lembaga pemerintah non struktural yang bersifat mandiri dan bertanggung jawab kepada presiden melalui menteri. Dalam melaksanakan tugasnya BAZNAS menyelenggrakan fungsi: (Baznas, 2017)

a. Perencanaa pengumpulan, Pendistribusian, dan pendayagunaan zakat.

b. Pelaksanaan pengumpulan, pendistribusian, dan pendayagunaan zakat.

c. Pengendalian pengumpulan, pendistribusian, dan pendayagunaan zakat.

d. Pelaporan dan pertanggungjawaban pelaksanaan pengelolaan zakat.

Dalam Undang-Undang tersebut menjelaskan bahwa peranan organisasi penerima zakat adalah sebagai lemabaga pengelola sekaligus penyalur dana kepada masyarakat. Namun untuk menjalankan fungsinya sebagai Badan Amil Zakat, BAZNAS dapat membentuk Unit Pengumpul Zakat (UPZ). UPZ tersebut dibentuk melalui Instansi Pemerintah, Badan Usaha Milik Negara, Badan Usaha Milik Daerah, Perusahaan Swasta, dan Perwakilan Republik Indonesia di Luar Nagara, serta dapat membetuk UPZ pada tingkat kecamatan, kelurahan dan lain sebagainya. Dari pemaparan tersebut dapat diketahui bahwa BAZNAS diberikan otoritas oleh pemerintah untuk mengelola dan mengkoordinasikan semua lembaga zakat, termasuk LAZ yang ada di Indonesia (Baznas, 2017).

\section{Lembaga Amil Zakat}

Dalam Undang-Undang Permerintah Republik Indonesia Nomor 23 Tahun 2011 pasal 17 tentang Pengelolaan Zakat menegaskan bahwa untuk membantu Badan Amil Zakat Nasional (BAZNAS) dalam melaksanakan 
pengumpulan, pendistribusian dan pendayagunaan zakat, maka masyarakat dapat membentuk Lembaga Amil Zakat (LAZ). Lembaga Amil Zakat merupakan lembaga pengelola zakat yang dibentuk oleh masyarakat yang pengukuhannya dilakukan oleh pemerintah bila telah memenuhi persyaratan tertentu (Baznas, 2017).

Lembaga Amil Zakat yang kemudian disebut dengan LAZ merupakan organisasi berbentuk badan hukum yang bertugas melakukan penerimaan, pengumpulan, pendistribusian, dan pendayagunaan zakat (Aflah, 2009: 11). Oleh sebab itu, untuk membantu BAZNAS dalam menjalankan fungsinya, sesuai dengan perundang-undangan, maka perlu dibentuknya LAZ. BAZNAS dan LAZ secara pengertian memang memiliki fungsi yang sama yaitu sebagai pengelola zakat. Namun di dalam hierarkinya sesuai dengan UU No 23 Tahun 2011 dimana LAZ sebagai Organisasi Pengelola Zakat yang berada dibawah naungan BAZNAS. Mengingat hal tersebut tercantum pada pasal 19 "LAZ wajib melaporkan pelaksanaan pengumpulan, pendistribusian, dan pendayagunaan zakat yang telah diaudit kepada BAZNAS secara berkala" (Mubarok \& Fanani, 2014). Adapun syarat Lembaga Amil Zakat yang di beri izin oleh Menteri dalam Undang-Undang Nomor 23 Tahun 2011 tentang pengelolaan zakat adalah sebagai berikut:

a. Terdaftar sebagai organisasi kemasyarakatan Islam yang mengelola bidang pendidikan, dakwah, dan sosial.

b. Berbentuk lembaga dan berbadan hukum.

c. Mendapat rekomendasi dari BAZNAS.

d. Memiliki pengawas syariat.

e. Memiliki kemampuan teknis, administratif, dan keuangan untuk melaksanakan kegiatannya.

f. Bersifat nirlaba.

g. Memiliki program untuk mendayagunakan zakat bagi kesejahteraan umat.

h. Bersedia diaudit syariat dan keuangan secara berkala.

Dari pemaparan diatas, dapat diketahui bahwa baik LAZ maupun BAZNAS merupkan lembaga yang berwenang dalam mengelola dan menyalurkan zakat sesuai dengan amanat perundang-undangan. Terlebih dalam Undang-Undang Perbankan Syariah nomor 21 tahun 2008 pasal 4 ayat 2 disebutkan bahwa peran perbankan syariah tidak hanya sebagai lembaga intermedisi keuangan tetapi juga berperan sebagai lembaga sosial dengan ikut mengelola dan menyalurkan zakat. Pada Undang-Undang tersebut dijelaskan bahwa perbankan syariah berperan sebagai lembaga sosial. Maksudnya adalah sebagaimana yang telah tertera dalam potongan QS. al-Maidah (5): 2 yang artinya: "Dan tolong- menolonglah kamu dalam (mengerjakan) kebaikan dan taqwa, dan jangan tolong- menolong dalam berbuat dosa dan pelanggaran. Dan bertaqwalah kamu kepada Allah, sesungguhnya Allah amat berat siksa-Nya". Dari pejelasan ayat diatas dapat dikemukakan bahwa bank syariah sebagai lembaga sosial berpegang teguh pada prinsip at-ta'awun. Dimana hal tersebut merupakan suatu prinsip untuk saling membantu dan bekerja sama antara anggota masyarakat dalam kebaikan (Mardani, 2014). Oleh sebab itu dalam hal pengelolaan dan penyaluaran zakat, diperlukan sinergi antara BAZNAS dan LAZ maupun dengan perbankan syariah. Sinergisitas tersebut dapat diterapkan sesuai dengan prinsip tolong-menolong dalam hal kebaikan yang dapat di implementasikan dalam bentuk pembiayaan usaha produktif.

\section{Skema Penyaluran Dana Zakat Produktif}

Salah satu tujuan dari penyaluran dana zakat adalah pemerataan kesejahteraan di antara umat Islam. Hal tersebut sejalan dengan kehadiran perbankan syariah di tengah masyarakat yang bertujuan untuk meningkatkan keadilan, kebersamaan, dan pemerataan kesejahteraan rakyat sebagaimana telah diatur dalam Undang-Undang nomor 21 tahun 2018 tentang perbankan syariah. Oleh sebab itu, lembaga pengelola zakat dapat bekerja sama dengan perbankan syariah dalam menyalurkan dana zakat (Putri dan Firmansyah, 2017). Dalam penyaluran pembiayaan modal usaha, perbankan syariah tidak dapat memberikan pembiayaan atau penyaluran dana secara langsung tanpa adanya pertimbangan penilaian yang dapat dijadikan sebagai dasar penyaluran dana. Oleh sebab itu, diperlukan manajemen risiko dalam penyaluran modal usaha perbankan syariah menerapkan prinsip 5 C (character, capital, capacity, collateral and condition) dalam melakukan mitigasi risiko (Solihin, 2014).

Character merupakan penilaian yang berakaitan dengan data individu seseorang, Capital merupakan penilaian kekayaan seorang individu, Capacity merupakan penilaian kemapuan seorang individu dalam memenuhi kewajiban hutang, Collateral merupakan penilaian aset jaminan, dan Condition merupakan penilaian pertimbangan kondisi ekonomi (Apriana dan Irwansyah, 2015). 
Dari kelima prinsip manajemen risiko penyaluran pembiaayaan yang telah dijelaskan diatas, dana zakat dapat memenuhi unsur collateral (jaminan), karena dana zakat dapat digunakan sebagai jaminan bagi mustakhik yang hendak mengajukan pembiayaan ke bank syariah. Jaminan yang didapat oleh perbankan syariah tersebut berupa dana zakat yang dikelola oleh lembaga pengelola zakat dalam bentuk cash collateral melalui simpanan deposito milik lembaga pengelola zakat dan dijamin oleh Lembaga Penjamin Simpanan. Sehingga, apabila mustakhik mengalami default (gagal bayar) maka simpanan deposito yang berasal dari dana zakat dapat dijadikan jaminan oleh perbankan syariah guna melakukan mitigasi risiko pembiayaan modal usaha (Putri dan Firmansyah, 2017).

Selain itu antara perbankan syariah dan lembaga pengelola zakat dapat berbagi peran dalam melakukan pendampingan kepada mustakhik yang mengajukan pembiayaan modal usaha. Bank syariah memberikan pendampingan dalam bentuk teknis usaha, sementara lembaga pengelola zakat melakukan pemdampingan dalam bentuk mental spiritual. Untuk mengetahui kolaborasi antara perbankan syariah dan OPZ dapat dilihat pada Gambar dibawah :
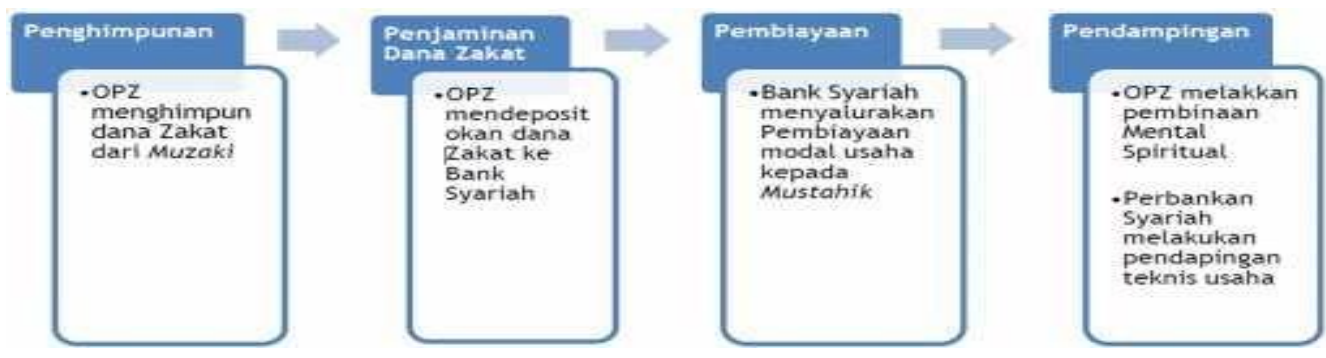

Gambar 1. Skema Kolabarasi Perbankan Syariah dan OPZ Sumber :INCOMFIN 2017

Dalam kondisi yang terjadi selama ini, permasalahan yang timbul adalah bahwa mustahik megalami kesulitan dalam hal permodalan, pengembangan usaha, serta daya saing produk yang dihasilkan. Maka diperlukan adanya pendampingan usaha antara Organisasi pengeloa zakat (OPZ) dan perbankan syariah untuk membantu mustahik dalam mengelola usahanya. Oleh sebab itu untuk membantu mustahik dalam mengelola usahanya dibutuhkan konsep metamorfosa mustahik (Putri \& Firmansyah, 2017). Mustahik bertujuan untuk memberdayakan mustahik yang pada awalnya menerima zakat, kemudian setelah dilakukan pemberdayaan pengelolaan usaha akan menjadi muzaki. Konsep tersebut sejalan dengan Undang-Udang nomor 21 tahun 2008 tentang perbankan syariah yang mengamanatkan bahwa: "Tujuan perbankan syariah adalah menunjang pembangunan nasional dalam rangka meningkatkan keadilan, kebersamaan, dan pemerataan kesejahteraan rakyat. Tujuan bank syariah sejalan dengan tujuan zakat dalam hal pemerataan kesejahteraan (Putri \& Firmansyah, 2017).

\section{Jenis-jenis Pembiayaan}

Badan amil zakat mengembangkan pola pendayagunaan dana zakat melalui tiga skema pembiayaan, yaitu pembiayaan murabahah, musyarakah, mudharabah (Amelia, 2012).

1. Pembiayaan Murabahah

Pembiayaan murabahah adalah jual beli barang pada harga asal dengan tambahan keuntungan yang telah disepakati. Dalam akad ini, penjual harus memberitahu harga produk yang ia beli dan menentukan suatu tingkat keuntungan sebagai tambahannya. Murabahah adalah akad jual beli barang dengan menyatakan harga perolehan dan keuntungan (Margin) yang disepakati antara penjual dan pembeli. Jual beli murabahah adalah jual beli barang pada harga asal dengan tambahan keuntungan yang telah disepakati. Akad murabahah yaitu pembelian barang dengan pembayaran yang ditangguhkan. Pembiayaan murabahah merupakan pembiayaan yang diberikan oleh bank syariah kepada nasabah dalam rangka pemenuhan kebutuhan produksi. Penerapan skema pembiayaan murabahah dapat dilihat pada ganbar dibawah ini 


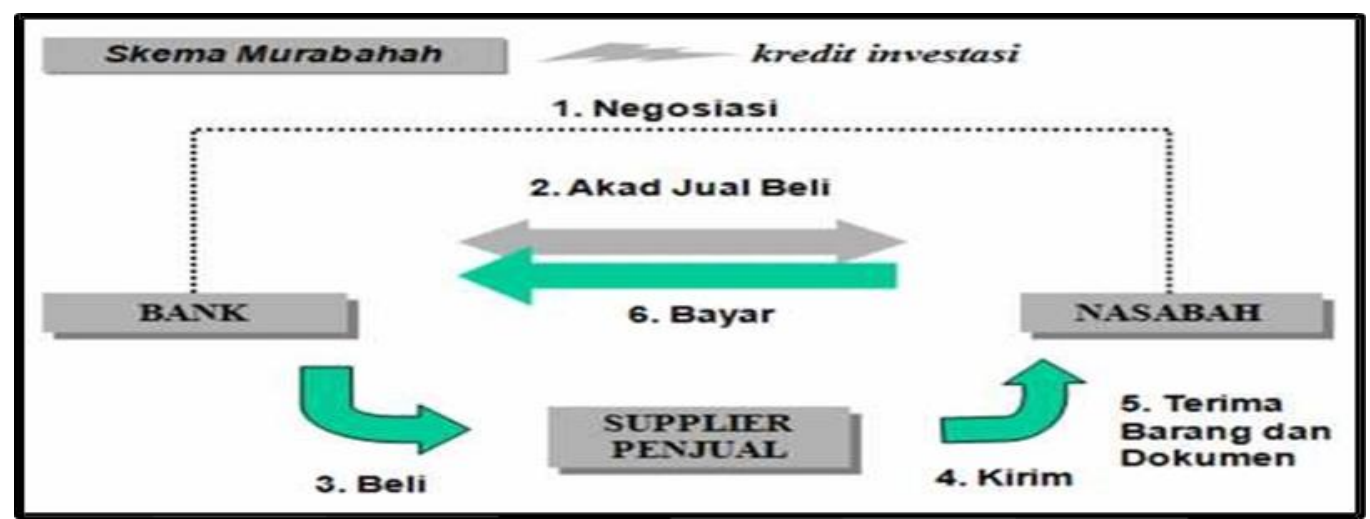

Gambar 2. Skema Pembiayaan Murabahah

(Sumber : Akad dan Produk Bank Syariah, 2007)

Pembiayaan murabahah merupakan salah satu konsep islam dalam melakukan perjanjian jual beli. Konsep ini telah banyak dilakukan oleh bank dan lembaga keuangan syariah yang lainnya untuk pembiayaan modal kerja serta pembiayaan modal nasabahnya.

2. Pembiayaan Musyarakah

Musyarakah adalah istilah yang sering dipakai dalam konteks skema pembiayaan Syariah. Pembiayaan Musyarakah merupakan akad bagi hasil ketika dua atau lebih pengusaha pemilik dana atau modal kerja sama sebagai mitra usaha membiayai suatu invest usaha baru atau yang sudah berjalan (Ascarya, 2013). Musyarakah adalah akad kerjasama usaha patungan antara dua pihak atau lebih pemilik modal untuk membiayai suatu jenis usaha yang produktif dan halal. Pendapatan atau keuntungan dibagi sesuai dengan rasio yang telah disepakati. Dalam penjelasan lainnya, musyarakah merupakan suatu pengkongsian antara dua pihak atau lebih dalam suatu proyek, dimana masing-masing pihak berhak atas segala keuntungan dan bertanggung jawab secara bersama pula apabila mengalami kerugian. Jadi musyarakah merupakan perjanjian yang berjalan terus sepanjang usaha yang dibiayai bersama terus beroperasi. Penerapan pembiayaan musyarakah dapat dilihat pada Gambar dibawah :

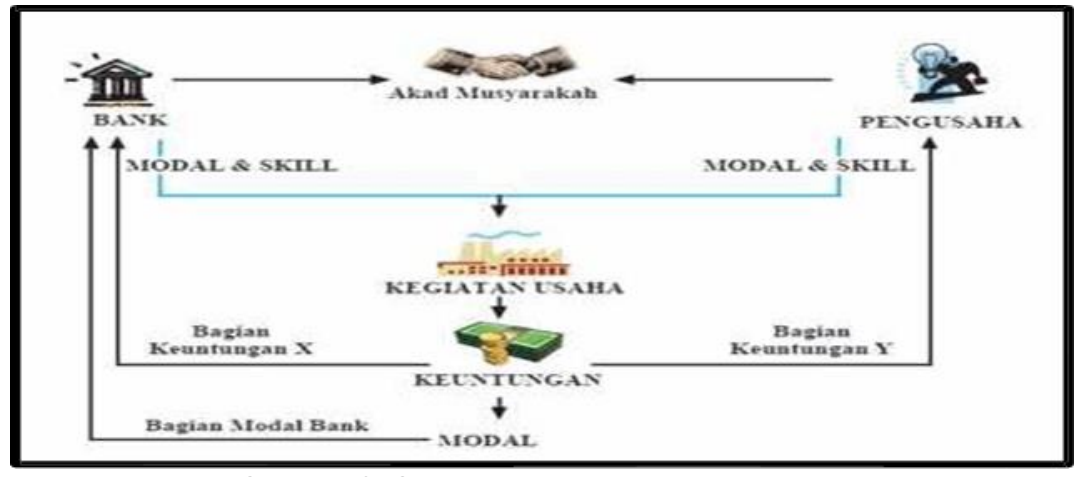

Gambar 3. Skema Pembiayaan Musyarakah

Sumber : Akad dan Produk Bank Syariah, 2007

3. Pembiayaan Mudharabah

Pembiayaan ini merupakan bentuk pembiayaan bagi hasil ketika bank sebagai pemilik dana atau modal, biasa disebut shahibul maal atau rabbul maal, menyediakan modal (100\%) sedangkan pihak lainnya menjadi pengelola. Keuntungan secara mudharabah dibagi menurut kesepakatan bersama yang dituangkan dalam kontrak yang disepakati bersama pula (Antonio, 2001: 95). Apabila terjadi kerugian karena proses normal dari usaha, dan bukan karena kelalaian atau kecurangan pengelola, kerugian ditanggung sepenuhnya oleh pemilik modal, sedangkan pengelola kehilangan tenaga dan keahlian yang telah dicurahkannya. Apabila terjadi kerugian karena kelalaian dan kecurangan pengelola, maka pengelola bertanggung jawab sepenuhnya (Ascarya, 2013). 


\section{Linkage Program Channeling}

Linkage Program adalah kerja sama bank umum dan Bank Perkreditan Rakyat yang dilandasi semangat kemitraan yang bersifat symbiosis mutualistik dengan tetap berorientasi pada aspek bisnis. Linkage program merupakan kerja sama strategis bagi penyaluran pembiayaan usaha mikro dan kecil (UMK). Agar bisnis dapat terus berkembang,berjalan dengan baik, mempunyai daya saing, dan terhindar dari kerugianyang tidak diinginkan, diperlukan penyempurnaan ketentuan yang diselaraskan dengan perkembangan situasi yang ada (Dapta, 2012). Berdasarakan peraturan Menteri Negara Koperasi dan Usaha Kecil dan Menengah Republik Indonesia Nomor 03/Per/M.KUKM/III/2009 tentang pedoman umum Linkage Program antara bank umum dengan koperasi, linkage program adalah program kerjasama antara bank umum termasuk bank umum peserta KUR dengan koperasi dalam rangka meningkatkan akses pembiayaan Usaha Mikro dan Kecil (UMK). Linkage program bertujuan untuk mengatasi masalah lembaga keuangan mikro yang selama ini cenderung kekurangan dana namun memiliki nasabah potensial yang cukup besar. Liknage program dibagi menjadi tiga yaitu Executing, Channeling, Joint Financing. Channeling merupakan pinjaman yang diberikan bank umum kepada anggota koperasi melalui koperasi yang bertindak sebagai agen dan tidak mempunyai wewenang memutus kredit kecuali mendapat surat kuasa dari bank umum sebagai pinjaman kepada anggota koperasi. Sedangkan pencatatan di koperasi sebagai off balance sheet (Mi'raj, 2015).

\section{Manajemen dan Fungsinya}

Manajemen berasal dari kata kerja to manage yang berarti kontrol, dan dalam bahasa Indonesia dapat diartikan sebagai mengendalikan, menangani atau mengelola. Kata manajemen mempunyai banyak arti, diantaranya 1) sebagai pengelolaan, pengendalian atau penanganan (managing), 2) perlakuan secara terampil untuk menangani sesuatu berupa skilful treatment, dan 3) gabungan dari dua pengertian tersebut, yaitu yang berhubungan dengan pengelolaan suatu perusahaan rumah tangga atau suatu bentuk kerjasama dalam mencapai suatu tujuan. Maka secara umum, pengertian manajemen adalah pengelolaan suatu pekerjaan untuk memperoleh hasil dalam rangka pencapaian tujuan yang telah ditentukan dengan cara menggerakkan orangorang lain untuk bekerja (Mardani, 2015). Manajemen merupakan proses mengkoordinir kegiatan pekerjaan secara efisien (tepat guna) dan efektif (tepat sasaran), dengan dan melalui orang lain. Yang dimaksud proses di sini adalah penggambaran fungsi-fungsi yang sedang berjalan atau kegiatan utama yang dilakukan oleh manajer. Dari beberapa penjelasan di atas pengertian manajemen menurut peneliti adalah proses kegiatan yang dilakukan secara efisien dan efektif untuk memperoleh suatu hasil dan digerakkan melalui orang lain (manajer). Manajemen ada dalam berbagai aspek kehidupan manusia di mana terbentuk dari suatu kerjasama (organisasi), seperti industri, pemerintahan, pendidikan, pelayanan sosial, dan lain-lain (Mardani, 2015).

\section{Kerangka Pemikiran}

Zakat berasal dari kata zaka yang berarti baik, berkah, tumbuh, bersih dan bertambah. Sedangkan menurut istilah fikih, zakat adalah nama bagi sejumlah harta tertentu yang dikeluarkan, dan diwajibkan oleh Allah SWT untuk diserahkan kepada orang yang berhak menerimanya (mustahiq) dari orang-orang yang wajib mengeluarkan (muzakki) (Khasanah, 2010). Dalam pendayagunaan dana zakat terbagi menjadi dua, yaitu zakat produktif dan zakat konsumtif (Fasiha, 201) yaitu zakat produktif dan zakat konsumtif, yang dikelola oleh institusi yang bergerak di bidang pengelolaan dana zakat, infaq, dan shadaqah. Dalam sejarah Islam lembaga pengelola zakat dikenal dengan nama Baitul Maal meliputi Badan Amil Zakat Nasional, Lembaga Amil Zakat. Oleh sebab itu dalam hal pengelolaan dan penyaluaran zakat, diperlukan sinergi antara BAZNAS dan LAZ maupun dengan perbankan syariah. Sinergisitas tersebut dapat diterapkan sesuai dengan prinsip tolong-menolong dalam hal kebaikan yang dapat di implementasikan dalam bentuk pembiayaan usaha produktif bagi lembaga menengah kecil dapat dilihat pada Gambar 4. 


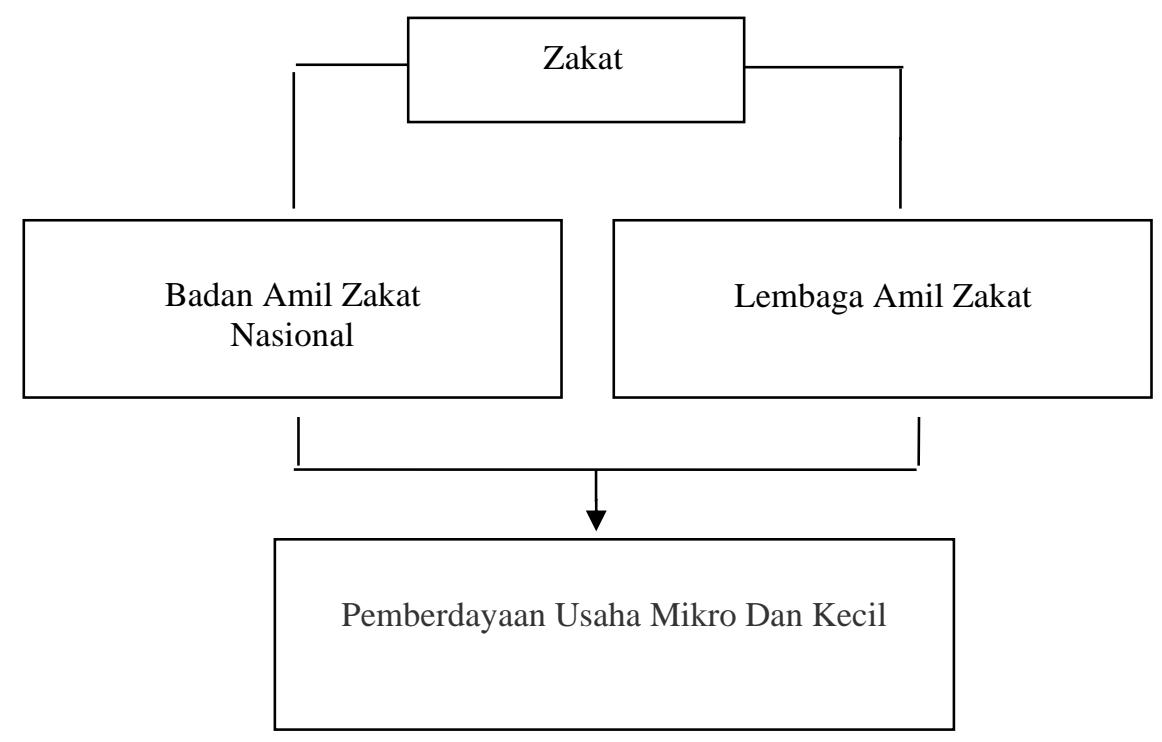

Gambar 4. Kerangka Pemikiran

\section{METODE PENELITIAN}

\section{Lokasi Objek Penelitian} Banda Aceh.

Lokasi objek penelitian ini adalah data yang diperoleh dari Badan Amil Zakat Nasional (Baznas) Kota

\section{Populasi dan Sampel Penelitian}

Populasi adalah wilayah generalisasi yang terdiri atas obyek atau subjek yang mempunyai kualitas dan karakteristik tertentu yang ditetapkan oleh peneliti untuk dipelajari dan kemudian ditarik kesimpulannya (Sugiyono, 2011). Populasi dalam penelitian ini adalah usaha mikro dan kecil yang diberdayakan oleh Badan Amil Zakat Nasional Kota Banda Aceh. Sampel dalam penelitian ini adalah usaha mikro dan kecil yang diberdayakan oleh Badan Amil Zakat Nasional Kota Banda Aceh. Teknik sampling yang digunakan adalah purposive sampling, dimana sampel adalah usaha mikro dan kecil yang diberdayakan oleh Badan Amil Zakat Nasional Kota Banda Aceh.

\section{Metode Pengumpulan Data}

Pendekatan penelitian yang digunakan dalam penelitian ini adalah pendekatan kualitatif. Penelitian kualitatif adalah suatu strategi inquiry yang menekankan pencarian makna, pengertian, konsep, karakteristik, gejala, simbol, maupun diskripsi tentang suatu fenomena; fokus dan multimetode; bersifat alami dan holistik; mengutamakan kualitas, menggunakan beberapa cara, serta disajikan secara naratif. Secara sederhana, tujuan penelitian kualitatif adalah untuk menemukan jawaban terhadap suatu fenomena atau pertanyaan melalui aplikasi prosedur ilmah secara sistematis dengan menggunakan pendekatan kualitatif (Sugiono, 2011).

\section{Variabel Penelitian}

Penelitian ini menggunakan variabel-variabel input yang meliputi:

1. Strategi pengembangan pemberdayaan usaha mikro dan kecil yang berarti langkah-langkah yang dimiliki Baznas dalam melakukan pemberdayaan usaha mikro dan kecil melalui usaha syariah.

2. Pembiayaan usaha syariah oleh Badan Amil Zakat Nasional didefinisikan sebagai jumlah modal yang diberikan Badan Amil Zakat Nasional berlandaskan syariah. 


\section{Operasionalisasi Variabel}

Berdasarkan pada penelitian-penelitian sebelumnya, variabel dalam penelitian ini terbagi menjadi :

1. Variabel Ouput

Variabel output adalah variabel yang menjadi pusat perhatian, dalam penelitian ini yang digunakan adalah pemberdayaan usaha mikro dan kecil (01). Pemberdayaan usaha mikro dan kecil (01) merupakan proses pengambilan keputusan orang-orang yang secara konsekuen melaksanakan keputusan-keputusan yang telah diambil tersebut. Orang-orang yang telah mencapai tujuan kolektif diberdayakan melalui kemandiriannya, bahkan merupakan sebuah keharusan untuk lebih diberdayakan melalui usaha mereka sendiri dan akumulasi pengetahuan, keterampilan dan sumber daya lainnya (Hikmat, 2010).

2. Variabel input

Variabel input adalah variabel yang mempengaruhi variabel output. Variabel input yang digunakan dalam penelitian ini adalah strategi pengembangan program pemberdayaan usaha mikro dan kecil. Strategi pengembangan program pemberdayaan usaha mikro dan kecil yaitu langkah-langkah yang dilakukan dalam pemberdayaan, yang menekankan pada proses memberikan bantuan dana agar dapat menjalankan usaha mikro dan kecil.

Tabel 1. Operasionalisasi Variabel

\begin{tabular}{|l|l|l|l|l|l|}
\hline No & \multicolumn{2}{|c|}{ Variabel } & \multicolumn{2}{c|}{ Satuan } & Skala Ukur \\
\hline 1 & $\begin{array}{l}\text { Strategi pengembangan program } \\
\text { pemberdayaan usaha mikro dan } \\
\text { kecil }\end{array}$ & $\begin{array}{l}\text { Langkah yang digunakan Baznas } \\
\text { untuk memberdayakan usaha } \\
\text { mikro dan kecil dalam bentuk } \\
\text { pendanaan }\end{array}$ & Dana & Nominal \\
\hline 1 & $\begin{array}{l}\text { Pemberdayaan usaha mikro dan } \\
\text { kecil }\end{array}$ & $\begin{array}{l}\text { Kemampuan usaha mikro dan } \\
\text { kecil menggunakan bantuan modal } \\
\text { dai Baznas }\end{array}$ & Hasil kegiatan & Nominal \\
\hline
\end{tabular}

\section{Jenis dan Sumber Data}

Perolehan data dalam penelitian ini menggunakan metode pengamatan, wawancara, dan dokumentasi.

1. Pengamatan

Pengamatan memungkinkan peneliti melihat dan mengamati sendiri, kemudian mencatat perilaku dan kejadian sebagaimana yang terjadi pada keadaan sebenarnya. Pengamatan dalam penelitian ini bersifat terbuka. Pengamat secara terbuka diketahui oleh subyek, sedangkan sebaliknya para subyek dengan sukarela memberikan kesempatan pengamat untuk mengamati peristiwa yang terjadi.

2. Wawancara

Wawancara adalah percakapan dengan maksud tertentu yang dilakukan oleh dua pihak, yaitu pewawancara (interviewer) yang mengajukan pertanyaan dan terwawancara (interview) yang memberikan jawaban atas pertanyaaan itu. Jenis wawancara yang digunakan adalan wawancara terbuka dan tidak terstruktur. Dalam wawancara tidak terstruktur peneliti belum mengetahui secara pasti data apa yang akan diperoleh, sehingga peneliti lebih banyak mendengarkan apa yang diceritakan oleh terwawancara pada pemiliki usaha mikro dan kecil (UMK) yang mendapatkan dana zakat dari Baznaz Kota Banda Aceh.

3. Dokumentasi

Dokumentasi adalah metode pengumpulan data dengan menyelidiki benda seperti buku, dokumen, dan peraturan, notulen rapat, catatan harian, dan sebagainya.

\section{Teknik Analisis Data}

Analisis data kualitatif adalah upaya yang dilakukan dengan cara bekerja secara terfokus kepada data, mengorganisasikan data, memilah-milah data menjadi satuan yang dapat dikelola, mensintesiskannya, mencari dan menemukan pola, menemukan apa yang penting dan apa yang dibutuhkan, dan memutuskan apa yang dapat diceritakan kepada orang lain. Teknik analisis data yang digunakan dalam penelitian ini adalah analisis data 
kualitatif mengikuti konsep Miles dan Huberman (1992) dalam Moleong (2011) proses analisis data kualitatif dilakukan secara interaktif dan berlangsung secara terus menerus pada setiap tahapan penelitian sehingga datanya sampai jenuh. Ada tiga komponen pokok yang harus diperhatikan dalam analisis data kualitatif yakni reduksi data, penyajian data dan penarikan kesimpulan atau verifikasi.

1. Reduksi Data

Analisis pertama yang dilakukan peneliti adalah pengumpulan data. Data yang dikumpulkan kemudian di reduksi yaitu menyeleksi, memfokuskan dan menyederhanakan data-data yang telah diproduksi, yang masih berupa data kasar sehingga peneliti berusaha memilih dan memfokuskan data yang relevan dengan permasalahan dan tujuan penelitian.

2. Penyajian Data

Analisis kedua, setelah data direduksi kemudian data disajikan dalam bentuk tulisan yaitu menyajikan informasi yang memungkinkan untuk dijadikan dasar penarikan kesimpulan penelitian. Penyajian data akan memudahkan peneliti memahami apa yang terjadi dan apa yang harus dilakukan berdasarkan pemahaman tentang penyajian data.

3. Penarikan Kesimpulan

Kesimpulan yang diambil ditangani secara longgar tetap terbuka sehingga kesimpulan yang semula belum jelas kemudian akan meningkat menjadi lebih rinci dan mengakar kokoh. Kesimpulan ini juga akan diverifikasi selama penelitian berlangsung dengan menguji maksud kebenaran, kekokohan dan kecocokannya yakni merupakan validitasnya.

\section{HASIL PENELITIAN DAN PEMBAHASAN}

\section{Gambaran Umum Program Pembiayaan Usaha Syariah (PUSYAR)}

Pusyar merupakan program pembiayaan usaha syariah kepada pelaku UKM di Kota Banda Aceh yang dalam hal ini bersifat perseorangan. Dalam program ini tidak membebankan biaya tambahan apapun kepada peminjam karena biaya margin, administrasi dan asuransi ditanggung oleh Badan Amil Zakat Nasional Kota Banda Aceh yang diambil dari dana infaq dan sedekah. Harapannya dari program Pusyar ini memberikan kebermanfaatan dan kesejahteraan bagi pelaku UKM. Pelaksanaan program Pusyar ini berlandaskan pada Perda No. 03 Pasal 20 Ayat 3 Tahun 2010 Pegelolaan Zakat, Infaq dan sedekah yang kemudian diaplikasikan pada nota kesepahaman kerjasama Pusyar. Program Pembiayaan Usaha Syariah (Pusyar) ini merupakan kerjasama dengan Badan Amil Zakat Nasional Kota Kota Banda Aceh, sebagai langkah konkrit dalam pemberdayaan UKM di Kota Banda Aceh, dengan cara memberikan pinjaman modal berbasis syariah dengan akad Murabahah. Gambaran program Pusyar (Lihat Gambar 1) adalah BPKK akan memberikan pembiayaan atau pinjaman dana kepada pengusaha mikro (yang bersifat perseorangan) dan kecil sebesar harga barang, dan nasabah wajib membayar kembali kepada bank sebesar harga barang dan keuntungannya (margin) secara angsuran. Namun keuntungannya margin dan biaya administrasi dan asuransi dibebankan kepada BAZ Kota Banda Aceh, seperti pada Gambar 5. 


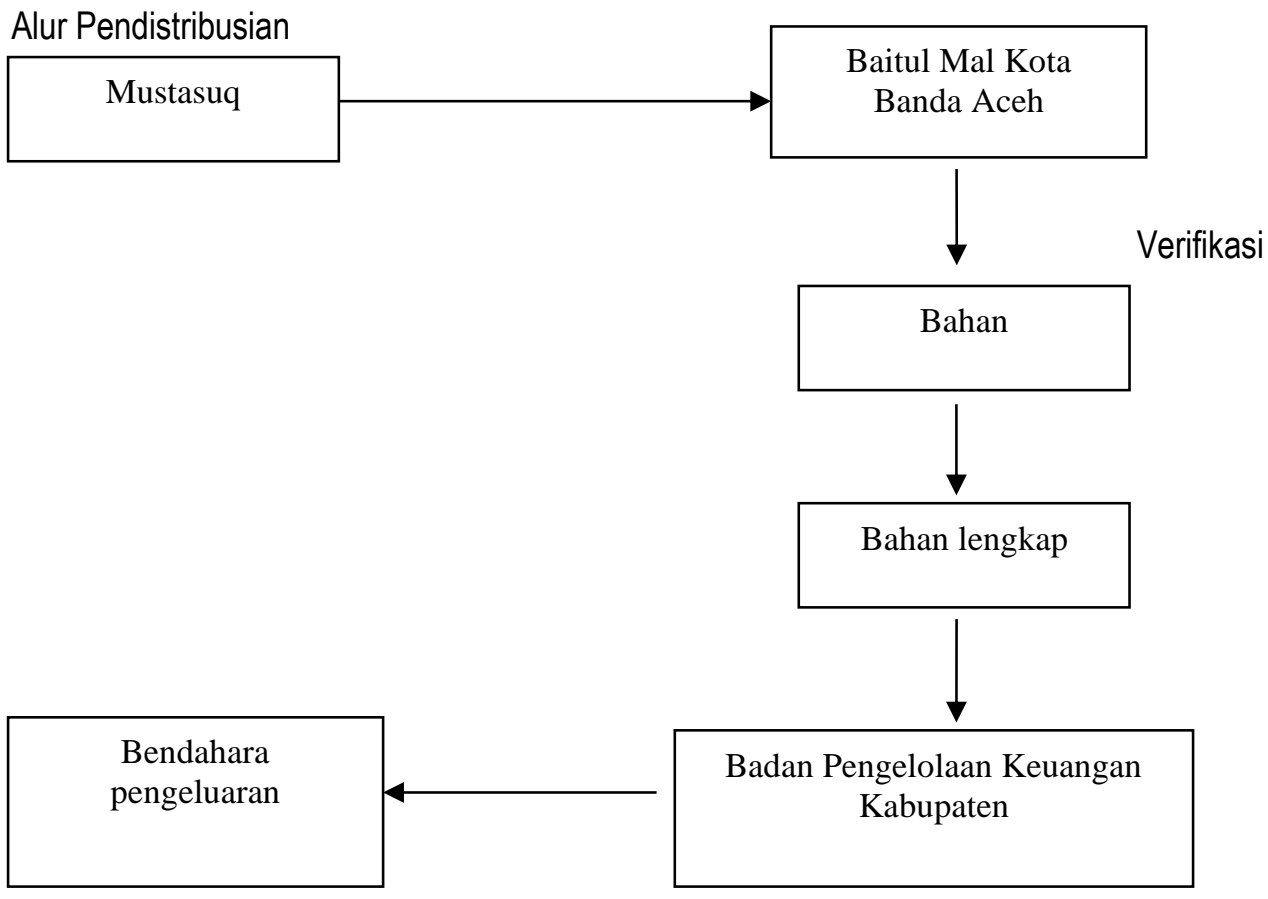

Gambar 5. Skema Program Pembiayaan Usaha Syariah

Keterangan:

1. Mustasuq/UKM perseorangan melakukan pengajuan pembiayaan ke Baitul Mal Kota Banda Aceh.

2. Baitul Mal Kota Banda Aceh melakukan verifikasi berkas sudah sesuai dengan kriteria yang ditentukan dan layak untuk diberikan pembiyaan.

3. BPKK memberikan bantuan pembiayaan Program Pusyar kepada UKM yang sudah diberikan rekomendasi kelayakan

4. UKM hanya berkewajiban membayar pokok dari pembiayaan yang sudah disalurkan oleh Baitul Mal Kota Banda Aceh.

5. Baitul Mal Kota Banda Aceh melalui dana infak bertanggung jawab atas margin pembiayaan, biaya administrasi dan biaya lainnya

\section{Gambaran Umum Badan Amil Zakat Nasional Kota Banda Aceh (Baitul Mal)}

Badan Amil Zakat Nasional (Baznas) merupakan badan resmi dan satu-satunya yang dibentuk oleh pemerintah berdasarkan keputusan presiden RI NO. 8 Tahun 2001 yang memiliki tugas dan fungsi menghimpun dan menyalurkan zakat, infaq dan sedekah (ZIS) pada tingkat nasional. Lahirnya undang-undang Nomor 23 tahun 2011 tentang pengelolaan zakat semakin mengukuhkan peran BAZNAS sebagai lembaga yang berwenang melakukan penegelolaan zakat secara nasional. Dalam UU tersebut, BAZNAS dinyatakan sebagai lembaga pemerintah nonstructural yang bersifat mandiri dan bertangung jawab kepada presiden melalui Menteri Agama. Dengan demikian, BAZNAS bersama pemerintah bertanggung jawab untuk mengawal pengelolaan zakat yang berasaskan: syariat islam, amanah, kemanfaatan, keadilan, kepastian hukum, terintegrasi dan akuntabilitas. BAZNAS menjalankan empat fungsi yaitu (BAZNAS, 2017) :

1. Perencanaan pengumpulan, pendistribusian dan pendayagunaan zakat.

2. Pelaksanaan pengumpulan, pendistribusian dan pendayagunaan zakat.

3. Pengendalian pengumpulan, pendistribusian dan pendayagunaan zakat.

4. Pelaporan dan pertanggunajawaban pelaksanaan pengelolaan zakat

Sedangkan Badan Amil Zakat Nasional (BAZNAS) yang ada saat ini adalah berawal dari Badan Amil Zakat Infaq dan Sadaqah (BAZIS) di lingkungan kantor wilayah Departemen Agama yang ada pada saat itu didirikan berdasarkan keputusan Kepala Kantor Wilayah Departemen Agama No. 25/KPTS/1989 tanggal 1 Mei 1989. Tujuan dibentuknya BAZIS ini adalah untuk menampung dan mengelola zakat yang ada di lingkungan Kantor 
Wilayah Departemen Agama pada saat itu. Pada perkembangan selanjutnya dengan keluarnya keputusan bersama Menteri Dalam Negeri dan Menteri Agama Republik Indonesia No. 29 tahun 1991 tentang pembinaan BAZIS, Opersaional BAZIS ini diperluas ke lingkungan pemerintah daerah Kota Banda Aceh yang dinamai dengan Lembaga Baitul Mal Kota Banda Aceh. Lembaga Baitul Mal Kota Banda Aceh terletak di jalan Malem Dagang No 40 Gampong Keudah Kecamatan Kuta Raja Kota Banda Aceh. Dasar hukum terbentuknya Baitul Mal Kota Banda Aceh, merupakan lembaga resmi pemerintah Kota Banda Aceh yang melaksanakan tugas pengumpulan, pengelolaan dan penyaluran zakat, infaq dan shadaqah serta harta agama lainnya dalam Wilayah Kota Banda Aceh yang di atur dalam beberapa peraturan :

1. Undang-undang No 11 tahun 2006 tentang Pemerintahan Aceh.

2. Qanun Aceh No 10 tahun 2007 tentang Baitul Mal.

3. Peraturan Walikota Banda Aceh No 3 tahun 2010 tentang Susunan Organisasi dan Tata Kerja Badan Pelaksana Baitul Mal Kota Banda Aceh..

4. Peraturan Walikota Banda Aceh No 34 tahun 2011 tentang Dewan Pengawas Baitul Mal Kota Banda Aceh.

5. Peraturan Walikota Banda Aceh No 70 tahun 2016.

6. Peraturan Walikota Banda Aceh No 32 tahun 2015 tentang pengelolaan zakat, infaq dan shadaqah.

Dalam rangka mendukung kinerja Baitul Mal Kota Banda Aceh makan di undangkan Qanun Kota Banda Aceh Nomor 5 Tahun 2010 tanggal 13 Desember 2010 tentang Susunan Organisasi dan Tata Kerja Sekretariat Lembaga Keistimewaan Kota Banda Aceh yang di dalamnya memuat Sekretariat Baitul Mal Kota Banda Aceh. Tugas pokok sekretariat adalah menyelenggarakan administrasi kesekretariatan, administrasi keuanganan, mendukung tugas fungsi lembaga Baitul Mal Kota Banda Aceh. Peraturan Walikota Banda Aceh Nomor 3 Tahun 2010 tanggal 8 Januari 2010 tentang susunanan organisasi dan tata kerja badan pelaksana Baitul Mal Kota Banda Aceh pasal 6 menyebutkan Kepala Baitul Mal menyelenggarakan fungsi sebagai berikut :

a. Pelaksanaan pendataan muzakki dan mustahik

b. Pelaksanaan pengumpulan zakat

c. Pendataan dan pengelolaan harta wakaf dan harta agama

d. Pelaksanaan penyaluran dan pendistribusian zakat

e. Pelaksanaan pembinaan, pendayagunaan dan pemberdayaan zakat, harta wakaf dan harta agama produktif.

f. Pelaksanaan sosialisasi dan pengembangan zakat, harta wakaf dan harta agama produktif.

g. Pelaksanaan penelitian, inventarisasi, klasifikasi terhadap pengelolaan zakat, harta wakaf dan harta agama.

$\mathrm{h}$. Pelaksanaan pengendalian dan pengawan urusan perwakilan sesuai dengan ketentuan syariat islam

i. Pelaksanaan penerimaan zakat, harta wakaf dan harta agama produktif.

j. Pelaksanaan pengelolaam terhadap harta yang tidak diketahui pemiliki atau ahli warisnya berdasarkan putusan Mahkamah Syar'iyah.

k. Pelaksanaan koordinasi dengan lembaga atau instansi terkait lainnya di bidang pengelolaan zakat, harta wakaf dan harta agama produktif.

Pelaksanaan tugas-tugas kedinasan lainnya yang diberikan Walikota sesuai dengan tugas dan fungsi serta peraturan perundang-undangan yang berlaku. 
Alur dana Baitul Mal

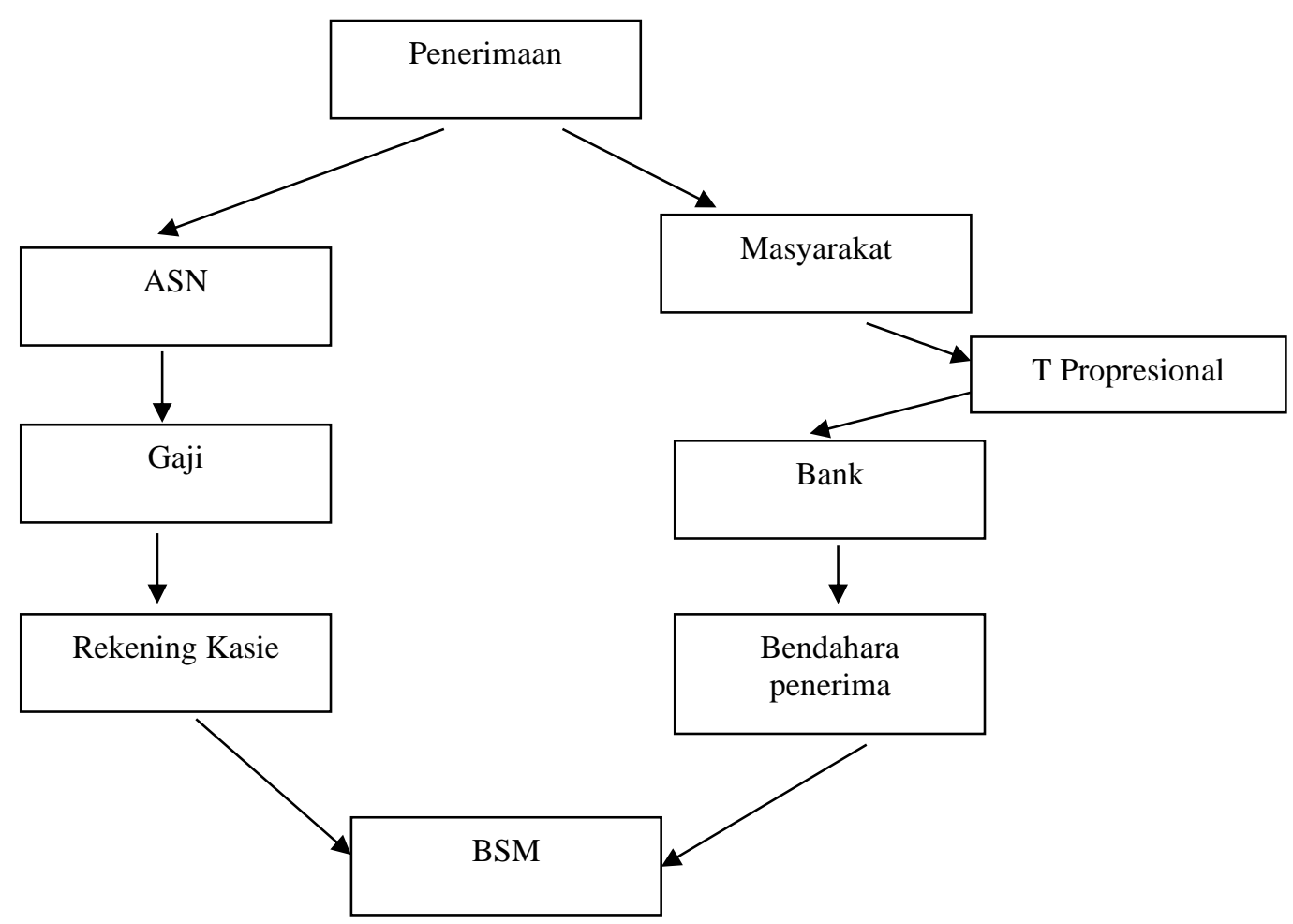

Gambar 6. Alur dana baitul mal

Berdasarkan data yang diperoleh dari Baitul Mal Kota Banda Aceh, dana bantuan modal usaha bergulir tahun 2018 berjumlah 255 unit usaha mikro dan kecil perseorangan yang berhasil disentuh melalui program pusyar ini. Berikut rincian program PUSYAR selama dua tahun berjalan, dan total Alokasi,realisasi dan jumlah UKM penerima program pusyar,dapat dilihat pada Tabel dibawah :

Tabel 2. UKM penerima program pusyar

\begin{tabular}{|r|c|c|c|}
\hline Tahun & Total Alokasi & Total Realisasi & Jumlah UKMM penerima (Unit) \\
\hline 2018 & 1.000 .000 .000 & 541.500 .000 & 255 \\
\hline 2019 & 1.000 .000 .000 & 571.000 .000 & 322 \\
\hline
\end{tabular}

Sumber : Baitul Mal Kota Banda Aceh (2018-2019)

Berdasarkan data dari Baitul Mal Kota Banda Aceh (2018-2019) menunjukkan bahwa alokasi dan realisasi dana Pusyar selama dua tahun pelaksanaan program tersebut mengalami peningkatan, begitu pula jumlah UKM penerima berfluktuatif dengan tren yang meningkat, sehingga diharapkan kebermanfaatan program Pusyar ini terus bisa meningkat. Jika dikaji dari aspek internal masalah yang dihadapi oleh Usaha Mikro dan Kecil di Kota Banda Aceh berasal dari sisi pelaku adalah lingkungan internal perusahaan yang merupakan sekumpulan sumber daya, kapabilitas dan kompetensi inti. Sumber daya, meliputi semua aset seperti keahlian, proses organisasi, atribut, informasi dan pengetahuan yang dikuasai oleh perusahaan dan yang menyebabkan perusahaan dapat menyusun dan mengimplementasikan strategi yang meningkatkan efisiensi dan efektivitas. Sehingga aspek internal merupakan faktor utama dalam strategi pengembangan usaha.

Sedangkan aspek eksternal berasal dari luar yang mendukung proses usaha serta ancaman dan risiko pasar di luar kehendak pelaku, sehingga setelah mengetahui problematika yang dihadapi oleh Usaha Mikro dan Kecil di Kota Banda Aceh, baik dari sisi internal maupun eksternal diperlukan sebuah strategi pengembangan yang tepat guna mengembangkan Usaha Mikro dan Kecil di Kota Banda Aceh. Pengembangan suatu usaha adalah tanggung jawab dari setiap pengusaha atau wirausaha yang membutuhkan pandangan kedepan, motivasi dan kreativitas. Jika hal ini dapat dilakukan oleh setiap wirausaha, maka besar harapan untuk dapat menjadikan 
usaha yang semula kecil menjadi skala menengah bahkan menjadi sebuah usaha besar. Berikut model strategi dan pengembangan Usaha Kecil dan Menengah melalui Program Pusyar yang diadopsi dari model strategi dan pengembangan usaha milik Rosyadi dapat diterapkan oleh stakeholders.

\section{KESIMPULAN DAN SARAN}

Berdasarkan analisis dan pembahasan dapat ditarik kesimpulan bahwa :

1. Program Pembiayaan Usaha Syariah (Pusyar) merupakan kerjasama Badan Amil Zakat Nasional Kota Banda Aceh Pemerintah Kota Banda Aceh, konsep dari program ini adalah memberikan pembiayaan pada Usaha Mikro dan Kecil dengan tidak membebankan biaya tambahan apapun kepada peminjam, karena biaya margin, administrasi dan asuransi ditanggung oleh Badan Amil Zakat Nasional Kota Banda Aceh yang diambil dari dana infaq dan sedekah.

2. Semua stakeholder yang terlibat memiliki peran dan tanggung jawab masing-masing agar program pembiayaan ini berjalan dengan lancer dalam penyediaan dana sebagai pinjaman yang diberikan kepada UKM di Kota Banda Aceh, Badan Amil Zakat bertanggung jawab dalam menanggung biaya yang timbul dari program Pusyar, seperti: biaya bagi hasil, biaya administrasi dan biaya asuransi peserta program Pusyar, calon peserta program Pusyar dan melakukan pengawasan terhadap usaha peserta program Pusyar dan pembinaan terhadap UKM peserta program Pusyar dalam manajemen usaha yang dilakukan oleh Masyarakat Ekonomi Syariah (MES).

3. Strategi pengembangan program pemberdayaan usaha mikro dan kecil melalui program pusyar dibagi menjadi empat kategori, antara lain: input, proses, ouput dan outcome. Pengembangan program pemberdayaan akan berhasil apabila pelaku usaha mikro dan kecil serta para stakeholder yang terlibat bersinergi terhadap peran dan tanggung jawabnya masing-masing.

\section{Saran}

a. Bagi peneliti

Penelitian ini diharapkan dapat menambah wawasan ilmu peneliti dalam mengembangkan diri dalam disiplin ekonomi syariah khususnya yang berhubungan dengan strategi pengembangan program pemberdayaan usaha mikro dan kecil melalui pembiayaan usaha syariah oleh Badan Amil Zakat Nasional.

b. Bagi peneliti lain

Penelitian ini diharapkan dapat menjadi baham masukan bagi peneliti lain yang ingin meneliti lebih lanjut, sehingga dapat menganalisis seara mendalam tentang mengenai strategi pengembangan program pemberdayaan usaha mikro dan kecil melalui pembiayaan usaha syariah oleh Badan Amil Zakat Nasional.

c. Bagi BAZNAS

Penelitian ini diharapkan dapat menjadi baham masukan mengenai faktor-faktor yang mempengaruhi strategi pengembangan program pemberdayaan usaha mikro dan kecil melalui pembiayaan usaha syariah oleh Badan Amil Zakat Nasional.

\section{REFERENSI}

Ali, dkk. (2016). Perbandingan Zakat Produktif dan Zakat Konsumtif dalam Meningkatkan Kesejahteraan Mustahik. Al-Muzara'ah. Vol. 4. No. 1. HIm 19-32.

Amelia, E. (2012). Penyaluran Dana Zakat Produktif Melalui Pola Pembiayaan (Studi Kasus BMT Binaul Ummah Bogor). Signifikan Vol. 1 No. 2. hlm 79-92.

Anwas, M Oos. (2014). Pemberdayaan Masyarakat di Era Globalisasi. Bandung : Alfabata. Ifabata.

Apriana, S., Dwi, W., \& Irwansyah. (2015). Analisis Pengaruh Prasyarat Kredit (5C) Terhadap Kelancaran Pembayaran Angsuran Nasabah Di Bank Kalsel Unit Sentra Antasari Banjarmasin. Jurnal Bisnis dan Pembangunan. hlm 10-18.

Ascarya. (2013). Akad dan produk Bank Syariah. Jakarta: Rajagrafindo Persada. Asnaini. (2008). Zakat Produktif dalam Perspektif Hukum Islam. Yogyakarta: Pustaka Pelajar. 
Asnaini, (2013). Zakat Produktif dalam Prespektif Hukum Islam, Ke-1. Yogyakarta: Pustaka Pelajar.

Aziz, A. (2016). Strategi Penghimpunan Dana Zakat Lima Lembaga Pengelola Zakat. Jurnal Syarikah. Vol. 2. No. 1. hlm 131-148.

Bank Indonesia. (2016). Pengelolaan Zakat yang Efektif. Jakarta: Departemen Ekonomi dan keuangan Syariah Bank Indonesia.

BAZNAS. (2015). Laporan Keuangan Badan Amil Zakat Tahun 2015. Jakarta: BAZNAS.

BAZNAS. (2017). Dampak Zakat Terhadap Kesejahteraan Mustahik Di Indonesia. Jakarta: Badan Amil Zakat Nasional.

Boedi, Abdullah, Beni Ahmad S. (2014). Metode penelitain Ekonomi Islam Muamalah. Bandung: Pustaka Setia.

Budiantoro, (2017). Strategi Pengembangan Program Pemberdayaan Usaha Mikro Dan Kecil Melalui Pembiayaan Usaha Syariah Di Kota Mojokerto. Magister Sains Ekonomi Islam, Universitas Airlangga, Surabaya risanda.abe@gmail.com

Chaniago. (2015). Pemberdayaan Zakat Dalam Mengentaskan Kemiskinan. Jawa Tengah : Jurusan Syariah dan Ekonomi Islam STAIN Pekalongan. sitiaminah@gmail.com.

Dapta, (2012). Perbedaan Pola Channeling dan Executing pada Pembiayaan Linkage Program di Bank Syariah Mandiri Cabang Salatiga.Sekolah Tinggi Agama Islam Negeri (STAIN) Salatiga. antika_sonya@yahoo.co.id

Fanani, A. M. (2014). Penghimpunan Dana Zakat Nasional. Permana. Vol 2. 7-8. Fasiha. (2017). Zakat Produktif (Alternatif Sistem Pengendalian Kemiksinan) (Cetakan ke-1 ed.). (M. R. Abdullah, Ed.) Palopo: Laskar Perubahan.

Fasiha., (2016). Pemikiran Ekonomi Ibnu Taimiyah, Jurnal Al Amwal, Vol 1. No. 2 September 2016.

Hikmat, Harry. (2010). Strategi Pemberdayaan Masyarakat. Bandung : Humaniora Utama Press.

Khasanah, Umrotul. (2010). Manajemen Zakat Modern. Malang: UIN-Maliki Press.

Kuncoro, (2016). Zakat: Katup Pengaman Keseimbangan Kehidupan Ekonomi Umat. Universitas Islam Sultan Agung (UNISSULA), Semarang. Email: anieskuncoro982@gmail.com.

Maltuf Fitri, (2016). Peran Dana Pihak Ketiga Dalam Kineria Lembaga Pembiayaan Syariah Dan Faktorfaktor Yang Memengaruhinya. Fakultas Ekonomi dan Bisnis Islam, UIN Walisongo Semarang.

Mardani. (2015). Aspek Hukum Lembaga Keuangan Syariah Di Indonesia. Jakarta: Kencana.

Mardani. (2014). Hukum Bisnis Syariah. Jakarta: Prenadamedia Group.

Mardikanto, Totok. (2015). Pemberdayaan Masyarakat. Bandung: Penerbit ALFABETA.

Mi'raj, (2015). Linkage Program Bank Syariah Dengan Bmt: Tinjauan Kritis Bagi Pengembangan Sistem Keuangan Islam Yang Lebih Kaffah. Program Studi S1 Ekonomi Islam-Fakultas Ekonomi dan Bisnis-Universitas Airlangga. Email : denizar_abdurrahman@yahoo.com

Moleong, L.J. (2011). Metodologi Penelitian Kualitatif Edisi Revisi. Bandung: PT. Remaja Rosdakarya. 
Mubarok, A., \& Fanani, B. (2014). Penghimpunan Dana Zakat Nasional (Potensi, Realisasi dan Peran Penting Organisasi Pengelola Zakat). Permana, Vol.5 No. 2. hlm 7-16.

Putri, S.A.M \& Firmansyah, E.J.R. (2017). Optimalisasi Laku Pandai berbasis Masjid una Literasi dan Inklusi Keuangan Syariah Berkelanjutan. Jurnal Ekonomi dan Bisnis Islam. Vol. 3. No. 2.

Prahesti, (2018). Pemberdayaan Usaha Kecil dan Mikro. Dana Zakat Produktif. IImu Dakwah: Academic Journal for Homiletic Studies

Septiandani. 2012. Sinergitas Peran Badan Amil Zakat Nasional (BAZNAS) dan Lembaga Amil Zakat Dalam Pengelolaan Zakat. Vol.5, No.1, Januari 2012.

Solihin, Ahmad, (2014), Buku Saku Panduan Zakat, LAZNAS Pusat Zakat Umat. Bandung.

Sugiyono, (2011). Metode Penelitian Kuantitatif, Kualitatif dan R\&D. Bandung: Afabeta

Wahyudi, Ahmad. 2016. Determinan Pembiayaan Murabahah pada Unit Usaha Syariah. Jurnal Bisnis dan Manajemen, Volume 6 (2).

Widiastuti dan Rosyidi, (2015). Model Pendayagunaan Zakat Produktif Oleh Lembaga Zakat Dalam Meningkatkan Pendapatan Mustahiq. Universitas Airlangga Email: widasus@yahoo.com 